\title{
Growth hormone and noonan syndrome: update in dysfunctional signaling aspects and in therapy for short stature
}

\author{
Patrick Raynal \\ Correspondence: patrick.raynal@univ-tlse3.fr

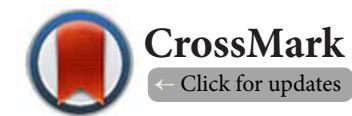

Université Paul Sabatier-Toulouse 3, M2CHRNRS, 118 route de Narbonne, F-31062 Toulouse, France.

\begin{abstract}
Short stature is a frequent feature of Noonan syndrome (NS), a disease caused by mutations of genes encoding components of the Ras/mitogen-activated protein kinases (MAPK) signalling pathway. To date numerous patients have been treated with growth hormone $(\mathrm{GH})$ in various countries. However this treatment is still controversial, as its efficacy is a matter of debate. The final height gain of GH therapy represents 5 to $10 \mathrm{~cm}$, at best, which is disappointing considering the length and burden of the treatment. The reasons explaining this lack of efficiency are poorly understood and they seemed to involve a waning effect after the first year of GH treatment or acceleration of bone maturation in patients on GH. Moreover, GH therapy raises questions about its safety, especially in subjects with NS who are at risk for cardiac defects and malignancies. Cases of severe adverse effects were described, yet too sporadically to conclude that they were certainly caused by GH therapy. Novels insights in understanding the dysfunction of GH-dependent processes in NS were recently reported and this manuscript aims at reviewing the latest advances. Clinical data suggested that growth retardation could be caused by a partial postreceptor resistance to GH, an impaired sensitivity to $\mathrm{GH}$ which could also explain the modest efficiency of GH therapy in NS patients. Similar observations were also obtained in a NS mouse model harboring a mutation in the gene encoding the tyrosine phosphatase Shp2. In the mouse, the mechanism of GH resistance is thought to involve upregulation by mutated Shp2 of GH-induced Ras/MAPK, a signaling pathway which seemed to play a negative regulatory role in the production of GH mediators involved in bone growth. Despite these recent finding, the underlying mechanisms of growth retardation and GH therapy in NS remain to be further explored in order to improve treatment for short stature.
\end{abstract}

Keywords: Noonan syndrome, growth hormone, PTPN11, shp2, ras/MAPK, rasopathy

\section{Introduction}

Noonan syndrome (NS) is a frequent $(\approx 1 / 1500-2000$ live births) autosomal dominant developmental disorder primarily characterized by short stature, typical facial features and heart defects. Patients with NS can also be affected with a variety of other symptoms including increased cancer risk, skin or bone defects, gastrointestinal issues, altered cognitive or/and psychosocial abilities etc. These manifestations are also observed, with different intensity, in related diseases including NS with multiple lentigines (also referred to as LEOPARD syndrome), Costello syndrome, cardiofaciocutaneous syndrome and neurofibromatosis-I. This family of clinically related disorders is now called the "Rasopathy" group, as they are caused by mutations in genes encoding components of the so-called Ras/mitogen-activated protein kinase (MAPK) pathway, an intracellular signaling pathway which primary function is to transduce signals from growth factor receptors to the cell nucleus. These genes include PTPN11, which is mutated in $\approx 50 \%$ of NS cases, SOS1 ( $\approx 10 \%)$, RAF1 $(\approx 10 \%)$, KRAS $(<2 \%)$, NRAS, $S H O C 2$ and CBL. Recently, RIT1, encoding a protein related to Ras, appeared as a novel NS-causing gene [1]. HRAS, MEK1, MEK2, NF1 and SPRED are additionnal genes which mutations can be responsible for other Rasopathies [2-4].
As a general mechanism for pathogenicity, the mutations causing NS induce, in most cases, an activation of the enzymes encoded by these genes. Most frequently this stimulation is moderate in terms of biochemical activity measured in vitro. However, in the cell or in vivo, these mutations result almost systematically in a higher-than-normal activation of the Ras/ MAPK pathway. This hyperactivation is thought to be responsible for the disease phenotype, as shown by studies in mice which began to explore the mechanisms involved in the pathogenicity of genes causing NS or other Rasopathies [5-7].

Several reviews have recently updated progress in epidemiology, etiology, diagnosis and treatment of clinical aspects of NS [2-4]. This current manuscript aims at examining in details the recent advances in understanding and treating short stature in in NS, as well as the latest progress in GH-dependent signalling pathways involved in short stature.

Short stature is one of the most frequent clinical manifestation of NS, even though adult final height may strongly vary from one patient to the other. In 2007, the U.S. Food and Drug Administration approved treatment of short stature caused by NS with recombinant growth hormone $(\mathrm{GH})$ in doses up to $66 \mu \mathrm{g} /$ $\mathrm{kg} /$ day. To date, numerous patients have been treated with $\mathrm{GH}$ in various countries. However GH treatment for NS is still 
Patrick Raynal Hormonal Studies 2014,

controversial. Indeed, the efficacy of GH therapy is a matter of debate, as data from the literature are sparse and difficult to compare between different reports, because of differing protocols and outcome criteria. In addition, $\mathrm{GH}$ treatment raises questions about its safety, especially in children who are at risk for cardiac defects and malignancies.

Other uncertainties about $\mathrm{GH}$ action in NS involves the mechanisms leading to short stature. Clinical data, as well as observations obtained in a NS mouse model, suggest that growth retardation could be caused by a partial postreceptor resistance to $\mathrm{GH}$, an impaired sensitivity to $\mathrm{GH}$ which could also explain the modest efficiency of GH therapy in NS patients. Recently, insights in these different issues have been reported and this manuscript aims at reviewing the latest advances.

\section{Characterization of short stature in NS} Spontaneous growth and adult height in patients with NS The question of final height in patients with NS remains a pending issue. Indeed, individuals with NS seem to have delayed bone age, their onset of puberty can be postponed by up to two years, and thus their growth may occur at an older age than normal subjects [8]. Therefore final adult height in NS subjects should be measured at the end of the second decade (at least in boys) and data reported at this age are not very abundant [9]. Nevertheless, it appears that about 30-50 \% of NS patients reach "normal" final adult height without treatment [10] (The height of an individual is defined as normal if it is above the $3^{\text {rd }}$ percentile on the growth chart relative to her/his peers, which corresponds to a height standard deviation score (SDS) for the individual's calendar age comprised between -2 and 2).

Reports on spontaneous growth in subjects with NS have shown varying results, especially in males. Earlier reports indicated that mean final height is $\approx 150-152 \mathrm{~cm}$ in girls and $\approx 160-162 \mathrm{~cm}$ in boys $[8,11]$. More recently, a mean adult height for males has been measured at $167 \mathrm{~cm}$ [12], or at 169 $\mathrm{cm}$ in a German study [13], which is higher than previously observed. In contrast, a study from Brazil found a mean final height of $148.4 \mathrm{~cm}$ in females and $157.4 \mathrm{~cm}$ in males [14], which is smaller than other studies. The origin of these discrepancies is not entirely clear. It could be due to ethnic differences or to a limited number of patients measured in these studies. However, it must be noted that the Brazilian report took into account only patients with confirmed molecular diagnosis. This allowed the inclusion of individuals with subtle phenotypes, whereas other studies included patients with clinical diagnosis, among which a significant proportion did not have a molecular diagnosis.

Interestingly, Wang et al., recently suggested that NS may be an underdiagnosed cause of delayed growth in patients with idiopathic short stature. Indeed, while screening candidate genes in a cohort of children with short stature and without known genetic etiology, they identified a few individuals with PTPN11 mutations causing NS, a disease which had not been yet diagnosed in these subjects [15].

Influence of genotype on spontaneous growth in subjects with NS

Different groups of clinicians reported a lower prevalence of short stature in patients with SOS1 mutations, compared with NS subjects harboring other genotypes [16-19]. In agreement, Malaquias et al., recently observed in 14 SOS1 patients a mean height SDS of $+0.4( \pm 0.8)$ compared to NS standard (which is thus composed, in majority, of subjects mutated in PTPN11) [14]. In this study, the authors also observed that individuals with BRAF mutations, similarly to those mutated in SOS1, have better preserved postnatal growth compared with patients harboring other genotypes [14]. In contrast, short stature seems to be more frequently associated with mutations of RAF1 (mean height SDS of $-0.5 \pm 0.9$ SDS compared to NS standards) or SHOC2 $(-1.3 \pm 0.7)[14,20,21]$. Nonetheless, it must be emphasized that these reports did not take into account a large number of patients, notably in the case of subjects with rare genotypes (e.g., SHOC2 mutations). Therefore it is likely that future studies involving more individuals will certainly amend these data, at least on a quantitative point of view. Additionnally, it remains to identify the mechanisms explaining how distinct genotypes can differentially influence the spontaneous growth of children with NS.

\section{GH therapy in NS}

What is the actual gain of GH therapy on patient's height? Thus far, data on final height after long term GH treatment are sparse and very few reports with appropriate controls on the effect of GH have been published. Most data reported in the literature have been obtained through observational studies on a limited number of patients, the majority of these investigations lacking a control group.

Despite these limitations, it is worthwhile to analyze the different reports which addressed this question [22-31]. Their data are summarized in Table 1. Although these studies do not all report outcomes at final height, this table suggests, as a whole, that the overall height gain under GH therapy is small, ranging from 0.8 to 1.4 in terms of height SDS increase. This represents a final height gain of 5 to $10 \mathrm{~cm}$ at best. At first sight, this may seem to be an outcome below expectations, considering the length, cost and burden of the treatment. However, when an increase of 5 to $10 \mathrm{~cm}$ in final adult height is effectively achieved, this can be considered as a reasonable result, considering that it may allow to reach normal adult height in a large subset of patients. It is also noteworthy that this range of increase in final height is similar with outcomes of GH-therapy in other non-GH deficient children. These include patients with Turner's syndrome who can usually gain a mean of $7 \mathrm{~cm}$ (range 5-15 cm) under GH therapy [4].

Among the data shown in Table 1, it is especially interesting to analyse the studies reporting $\mathrm{GH}$ therapy effects in patients who reached adult or near adult height. Intriguingly, these 
Patrick Raynal Hormonal Studies 2014,

http://www.hoajonline.com/journals/pdf/2052-8000-2-1.pdf

doi: $10.7243 / 2052-8000-2-1$

Table 1. Results are mean values unless otherwise specified. Height SDS is reported according to general population standards.

\begin{tabular}{|c|c|c|c|c|c|c|c|}
\hline Reference & $\begin{array}{l}\text { Number of } \\
\text { patients } \mathbf{n}(\mathbf{n}+)\end{array}$ & $\begin{array}{l}\text { Baseline } \\
\text { age year }\end{array}$ & $\begin{array}{l}\text { Baseline } \\
\text { height SDS }\end{array}$ & $\begin{array}{l}\text { GH dose } \\
m g / k g / \text { week }\end{array}$ & $\begin{array}{l}\text { Duration of } \\
\text { therapy year }\end{array}$ & $\begin{array}{l}\Delta \text { height SDS } \\
\text { after therapy }\end{array}$ & $\begin{array}{l}\text { Height gain at } \\
\text { adult age } \mathrm{cm}\end{array}$ \\
\hline Kirk et al., 2001 [22] & $10(4)$ & 12 & -3.1 & 0.30 & 5.3 & 0.8 & 3.1 \\
\hline Mcfarlane et al., 2001 [23] & $23(7)$ & 9.3 & -2.7 & 0.33 & 3 & 0.8 & N.A. \\
\hline Ogawa et al., 2004 [24] & $15(7)$ & 7.5 & -2.8 & $\approx 0.17$ & 2 & 0.6 & N.A. \\
\hline $\begin{array}{l}\text { Binder et al., } 2005 \text { [25] } \\
\text { Mut+ } \\
\text { Mut- }\end{array}$ & $\begin{array}{l}8 \text { (N.A.) } \\
3 \text { (N.A.) }\end{array}$ & $\begin{array}{l}7.4 \\
6.3\end{array}$ & $\begin{array}{l}-3.46 \\
-3.80\end{array}$ & $\begin{array}{l}0.29 \\
0.35\end{array}$ & $\begin{array}{l}1 \\
1\end{array}$ & $\begin{array}{l}0.66 \\
1.26\end{array}$ & $\begin{array}{l}\text { N.A. } \\
\text { N.A. }\end{array}$ \\
\hline Osio et al., 2005 [26] & $18(11)$ & 8.7 & -2.9 & $\begin{array}{l}0.23-0.46 \\
\text { range }\end{array}$ & $\approx 9.8$ & 1.7 & $13\left(\delta^{\Uparrow}\right) 9.8(+\circ)$ \\
\hline $\begin{array}{l}\text { Liman et al., } 2006 \text { [27] } \\
\text { Mut+ } \\
\text { Mut- }\end{array}$ & $\begin{array}{l}15 \text { (N.A.) } \\
10 \text { (N.A.) }\end{array}$ & $\begin{array}{l}10.4 \\
10.3\end{array}$ & $\begin{array}{l}-3.5 \\
-3.0\end{array}$ & $\begin{array}{l}0.3 \text { or } 0.46 \\
0.3 \text { or } 0.46\end{array}$ & $\begin{array}{l}2 \\
2\end{array}$ & $\begin{array}{l}0.4 \\
1.0\end{array}$ & $\begin{array}{l}\text { N.A. } \\
\text { N.A. }\end{array}$ \\
\hline Noordam et al., $2008[28]^{*}$ & $29(8)$ & 11 & -2.8 & 0.35 & 6.4 & 1.3 & N.A. \\
\hline $\begin{array}{l}\text { Raai jmakers et al., } 2008 \\
{[29]^{*}}\end{array}$ & 24 (N.A.) & $\begin{array}{l}10.2 \\
\text { median }\end{array}$ & $\begin{array}{l}-3.24 \\
\text { median }\end{array}$ & $\begin{array}{l}0.17-0.77 \\
\text { range }\end{array}$ & $\begin{array}{l}7.59 \\
\text { median }\end{array}$ & $\begin{array}{l}0.87 \\
\text { median }\end{array}$ & N.A. \\
\hline Romano et al., 2009 [30] & $65(30)$ & 11.6 & -3.5 & 0.33 & 5.6 & 1.4 & $10.9($ đ) $9.2(+)$ \\
\hline Lee et al., 2012 [31] & $120(30)$ & 9.2 & -2.65 & $\begin{array}{l}0.33-0.41 \\
\text { range }\end{array}$ & 4 & 1.33 & N.A. \\
\hline
\end{tabular}

Baseline age: age at start of therapy

$\Delta$ height SDS after therapy: increase in height SDS after therapy

N.A., Not available; ${ }^{\star}$ Same research group

Mut+, patients mutated on PTPN11; Mut-, patients not mutated on PTPN11.

studies may be distinguished in two classes, depending on the extent of the increase of height SDS they report. Thus Kirk et al., observed a moderate increase in height SDS of 0.8 in 10 patients [22], which is in accordance with a rise of 0.87 in 24 patients reported by Raaijmakers et al., [29]. On the other hand, Osio et al., Noordam et al., and Romano et al., reported better outcomes of GH therapy, with increases in height SDS ranging from 1.3 to 1.7 on a total of 112 patients $[26,28,30]$.

Various factors were proposed to explain these discrepancies between studies, in addition to the limitations described above. One of these factors is duration of therapy. For example, in the study by Kirk et al., patients were treated on average for 5.3 years, whilst reports by Osio et al., or Noordam et al., are based on subjects treated for longer duration (9.8 and 6.4 years, respectively). Nevertheless, other factors appear to be involved in these discrepancies, since patients treated for 7.6 years in the Raaijmakers' study failed to show an increase of height SDS above 0.87 (Table 1).

One of these factors is certainly children's age at start of therapy. Indeed, an earlier initiation of treatment is thought to result in a better outcome, as longer duration of GH therapy during the prepubertal period was found to produced greater height gains $[26,30]$. It is also important to consider that the link between earlier start of GH therapy and optimal height gain has been also observed in other growth-related disorders, including Turner's syndrome [4,32]. However, this view must be somewhat balanced with the fact that $\mathrm{GH}$ therapy has an accelerating effect on bone age, which may eventually reduce the benefit of $\mathrm{GH}$ treatment, considering that patients on $\mathrm{GH}$ could terminate their growth earlier than in untreated individuals (Cf. 2.2.2).

An additional source of variation between the above studies could be due to different doses of GH used in these studies, even though no significant correlation of given dosage to final height has been found to date $[\mathbf{2 2}, \mathbf{2 6}, \mathbf{2 8}]$. For example, Osio et al., did not observe a significant difference between two sets of nine patients receiving 0.23 or $0.46 \mathrm{mg}$ of $\mathrm{GH}$ per $\mathrm{kg}$ and per week [26]. Nevertheless, additional studies are certainly required to define more accurately the role of each of these factors in the efficiency of GH therapy.

An important, yet poorly studied, aspect of GH therapy is the psychological impact of this treatment in children with NS. Besides the fact that the attitude of patients' parents is essential for treatment compliance on the long term, Westphal indicated that short stature can represent a further stigma in children who may be already perceived as different from "normal" subjects. On the other hand, daily injection of GH could increase the perception of being ill in these patients [33]. Studies are thus required to examine with attention the psychological consequences of GH therapy in NS patients, a question which interest is reinforced by the fact that NS patients may be at risk for elevated anxiety or depression $[34,35]$.

Another significant issue of GH therapy is treatment cost. Analyses based on cases of Turner's syndrome or idiopathic short stature assessed this cost as 33,750 to 35,000 US\$ per 
Patrick Raynal Hormonal Studies 2014,

centimeter of height gained. However, recent market entry of new competitors and/or generics is expected to decrease this cost by $\approx 60 \%$, an economic progress that should indirectly contribute to the prescription of GH therapy to more NS patients [36,37].

\section{Hypothetical mechanisms illustrating the reduced outcome of GH therapy in NS Waning effect of GH therapy}

As shown above, GH therapy in patients with NS appeared to have a limited effect on short stature, even though additional investigations are still required to define precisely the effect of GH therapy. The explanations for this lack of efficiency are unclear. An important aspect of this issue has been revealed by reports showing a waning effect of $\mathrm{GH}$ therapy after the first year of treatment. For example, Kirk et al., observed on a sample of 66 patients treated with GH an increase of height SDS of 0.3 during the first year of therapy, which was followed by a similar increase when considering as a whole the 5 following years [22]. Similarly, MacFarlane et al., measured, in 19 individuals treated with $\mathrm{GH}$, height velocity of $8.4 \mathrm{~cm}$ for the $1^{\text {st }}$ year of treatment, then 6.2 and $5.8 \mathrm{~cm} /$ year for the two following years [23]. On the same theme, Raaijmakers et al., observed increments of $0.54,0.13$ and 0.13 in height SDS for 3 successive years, respectively [29].

The mechanism of this waning effect is unknown and further investigations are necessary to address this question and define the factors influencing this effect. Recently Lee et al., reported an absence of waning effect of GH therapy [31]. The reason for this discrepancy with former studies is unclear but this latter study only included a small set of seven patients, and the dose of $\mathrm{GH}$ given to the patients was slightly increased each year, which might thus have compensated for the waning effect.

\section{Acceleration of bone maturation by GH therapy}

As mentioned above, subjects with NS seem to have delayed bone age, and thus their growth may occur at an older age than normal individuals [8]. Thus, Noordam et al., proposed that the lack of efficiency of GH therapy could be due, at least partially, to the accelerating effect of GH on bone maturation. Indeed, they observed that bone development was significantly faster in a group of NS patients treated with $\mathrm{GH}$, compared with subjects not receiving $\mathrm{GH}$. Thus, whereas patients under $\mathrm{GH}$ therapy may grow faster than untreated subjects, their final height might be compromised by accelerated maturation of bone which should terminate their growth earlier than in untreated individuals [38]. However, at this stage of our knowledge, the actual contribution of this hypothetical mechanism in restraining GH therapy efficiency must be further explored.

\section{Other mechanisms}

In addition to the above mechanisms, it appears to date that the limited effect of GH therapy on the growth of children with NS could be linked to the fact that patients may present mild GH resistance due to a defective postreceptor signaling. This GH insensitivity could be also the cause for short stature. Therefore this theme will be discussed in chapter 3 .

\section{Potential adverses effects of GH therapy}

Besides the fact that GH therapy has a limited effect on patient's final height, this treatment raises safety questions in children affected by a syndrome with frequent cardiac defects and increased risk of malignancies.

From studies in acromegalic patients and in transgenic mice, it is known that long-standing elevated GH increases ventricular wall thickness, which can ultimately lead to long-term pathological structural and functional changes in the heart [39]. The effects of GH treatment on the heart of subjects with NS were assessed in a few prospective studies, which included children with cardiac defects (none of them with severe hypertrophic cardiomyopathy) [40-42]. These reports did not show major changes of cardiac dimensions in $\mathrm{GH}$-treated individuals, compared to the group of control subjects. However the significance of these data is somewhat restricted by the reduced number of patients followed up and by the limited duration of the $\mathrm{GH}$ treatment in these studies (range 1-3 years), in comparison with the much longer extent of GH therapy required to improve growth in patients with NS.

Other studies reported adverse effects of GH therapy at the heart level. For example, Noordam pointed out that cardiac adverse reactions were reported in 7 subjects among 429 children with NS treated with GH. These adverse effects include 1 cyanotic episode, 3 cardiac arrhythmias, 1 angina pectoris, 1 severe left ventricular hypertrophy and 1 cardiomyopathy necessitating heart transplant. They occurred after different lengths of treatment (2-10 years) [43]. Similarly, Romano et al., identified 5 cardiac events among the combined 889 patients from studies that reported adult-height outcomes in patients with NS on GH. These cardiac events included 2 mild progressions of pulmonic stenosis, 1 hypertrophic cardiomyopathy, 1 increased biventricular hypertrophy and 1 cardiac decompensation [44].

In addition to cardiac adverse effects, the risk of promoting tumorigenesis is another important concern about GH therapy. Indeed it is well known that, as a consequence of harboring mutation of genes of the Ras/MAPK pathway, subjects with NS display spontaneously an increased risk of developing cancer, and notably juvenile hematological malignancies $[3,45]$. This susceptibility to cancer is certainly a consequence of the mutations causing NS which are located in genes of the Ras/MAPK pathway, a signaling module that regulates cell proliferation or survival in a variety of different tissues. Consequently, GH therapy could potentially aggravate the risk of developing cancer in subjects with NS, considering that GH can also contribute to the activation of Ras/MAPK or other proliferative signaling pathway, either directly through 
Patrick Raynal Hormonal Studies 2014,

its own GH receptor, or through long-term elevated IGF-1 concentration resulting from $\mathrm{GH}$ treatment.

Thus far the question of whether GH therapy further increases the risk of tumorigenesis in NS patients is not definitely close, even though the issue of GH safety has been studied with attention in follow-up studies $[23,31]$. A few reports mentioned cases of tumorigenesis (1 lymphoma and 1 skin tumor) in children treated with $\mathrm{GH}$ but these appeared too sporadically to conclude with confidence that they were caused by GH treatment $[26,46]$. Moreover, it must be taken into consideration that early cancer is more frequent in NS patients than in the general population $[2,3]$. Therefore, these cases of tumorigenesis can be also observed in NS subjects without GH therapy. In addition to cardiac and neoplasic adverse effects, GH therapy could potentially interfere with bone homeostasis and with carbohydrate and lipid metabolism. Supporting this view, 6 cases of scoliosis were reported in a panel of 65 patients under GH therapy [30]. Nevertheless, it is important to consider that scoliosis is not rare in NS. Therefore further studies are required to define whether $\mathrm{GH}$ therapy has a negative influence on the frequency of this manifestation.

The concern for putative metabolic dysregulations caused by $\mathrm{GH}$ is due to the well-known effect of $\mathrm{GH}$ as promoting a mild form of insulin resistance. Supporting this view, Osio and collaborators observed a slight temporary increase in fasting insulin levels in a small number of NS children treated with $\mathrm{GH}$. However, in this set of patients, other markers of altered glucose metabolism were within the normal range [26].

Moreover, it was recently reported that patients with NS have a mean body mass index lower than normal subjects $[13,14]$. Although this observation requires to be confirmed in larger groups of patients, it is not totally unexpected when considering certain reports which addressed the function of Shp2 (the PTPN11 gene product) in the mouse metabolism. For example, expression of a dominant active mutant of Shp2 (which is biochemically comparable to a mutant causing NS) in the mouse brain leads to resistance to high fat diet-induced obesity and to improved insulin sensitivity [47]. Consequently it is possible to speculate that NS patients could be somewhat protected from metabolic disorders, which could minimize the possible adverse effects of $\mathrm{GH}$ therapy on carbohydrate and lipid metabolism. Studies in patients and in animal models of NS are under way to investigate this intriguing question.

To conclude this chapter on adverse effects of GH therapy, it must be emphasized that, whatever the type of adverse reaction, additional studies are needed to investigate these issues, as, to date, it seems difficult to draw any definite conclusion.

\section{Mechanism(s) explaining short stature in NS Hypotheses drawn from clinical observation Feeding difficulties}

Various hypothesis were proposed to explain the origin of short stature in NS. Initially, as children with NS frequently display feeding difficulties during their first years of life, this was thought to explain their delay in thriving during this period. However, feeding issues are no longer considered as a major cause of growth retardation in NS, as feeding difficulties usually improve after the first year of life, whilst children remain short for their age [10].

\section{Neurosecretory defects in GH secretion}

Another possible cause for growth retardation was provided by the description of signs of neurosecretory dysfunctions at the level of GH secretion in children with NS [48]. Nevertheless, recent data showed that the majority of NS patients have normal or elevated concentrations of circulating GH, which argues against the view that short stature in NS could be primarily due to impaired GH secretion $[25,27]$.

\section{Defects in bone homeostasis}

An emerging hypothesis regarding the cause of growth issues in NS speculates on the existence of dysfunctions at the bone level, through putative defects in the growth plate. This idea is based on the observation that orthopedic manifestations are a common feature of Rasopathies. In the case of NS, scoliosis and other spinal deformities are frequently encountered $[49,50]$ and it was recently reported that NS children may have decreased bone mineralization [51], even though this study was performed on a limited number of patients. This hypothesis is also based on a recent report showing that PTPN11 disruption causes severe skeletal defects in mice [52]. Nonetheless the validity of this hypothesis has not been tested yet.

\section{Signs of $\mathrm{GH}$ resistance}

To date, the leading hypothesis about the origin of growth impairment in NS postulates that patients present a mild resistance to GH (at least those harboring PTPN11 mutations). This partial insensitivity to $\mathrm{GH}$ could be the consequence of putative postreceptor signaling defects, which seem to be partially compensated for by elevated concentrations of circulating $\mathrm{GH}$. This view is based on the fact that all the genes causing NS are involved, at least in theory, in the processes of intracellular signaling activated by the $\mathrm{GH}$ receptor, considering that Ras/MAPK is one of the major signaling pathway stimulated by this receptor. Moreover, this hypothesis was strongly supported by recent reports showing that patients with normal or increased GH levels display lower-than-normal concentrations of insulin-like growth factor (IGF)-1, IGF-binding protein (IGFBP)-3 and acidlabile subunit (ALS) $[\mathbf{2 5 , 2 7 ]}$ (IGF-1 is a major mediator of GH action, as it directly promotes the growth of long bones and its production is upregulated by GH; along with IGF-1, the functional action of $\mathrm{GH}$ on bone growth can be assessed by assaying the circulating concentrations of IGFBP-3 and ALS, which production is also stimulated by $\mathrm{GH}$ ).

Interestingly, these reports also suggested that the extent 
Patrick Raynal Hormonal Studies 2014,

of $\mathrm{GH}$ resistance was more pronounced in individuals with PTPN11 mutations than in patients not mutated in this gene. Indeed, the decrease of IGF-1, IGFBP-3 and ALS levels has a tendency to be more pronounced in children harboring PTPN11 mutations than in patients with other mutations. In agreement with this, individuals mutated in PTPN11 appeared to respond less to $\mathrm{GH}$ therapy than other NS patients $[\mathbf{2 5 , 2 7 ]}$.

Supporting the concept of $\mathrm{GH}$ resistance in patients with PTPN11 mutations, other clinicians subsequently reported that these individuals display, under GH therapy, smaller increments in IGF-1 levels or in short-term growth, compared with subjects without PTPN1 1 mutations $[\mathbf{2 8}, \mathbf{5 3}]$. However, in one of these studies which also measured patients growth, long-term GH treatment was not found to make a significant difference on the growth of children harboring PTPN11 mutations, in comparison with other NS patients [28]. Supporting this later observation, a recent study failed to find different levels of basal IGF-1 and IGFBP-3 between patients with or without PTPN11 mutations, while this study did confirm that NS patients, harboring or not PTPN11 mutations, have abnormally low levels of IGF-1 and IGFBP-3 in comparison with normal subjects [54]. However, a recent study measuring IGF-1 after stimulation of $\mathrm{GH}$ secretion did find a significant difference between 12 NS patients harboring PTPN11 mutations and 12 children with idiopathic short stature as control group. Indeed, the increase of IGF-1 following stimulation of GH secretion was significantly blunted in the first group, compared to the control group [55].

Therefore, it seems that a consensus view is established on the fact that NS patients display signs of GH resistance. In contrast, the question of whether patients with PTPN11 mutations are less sensitive to $\mathrm{GH}$ than other patients is still a matter of debate. Discrepancies on this issue between the above reports could be explained by the small number of patients available in these studies and by the fact that the group of "NS subjects without PTPN11 mutations" does not seem to represent an appropriate control group in these studies. Indeed, as seen in chapter 1.2., recent data indicate the existence of significant differences between patients in this group, considering, for example, that patients with mutations of SOS1 or BRAF display a lower prevalence of short stature. Thus long term correlation between genotype and GH therapy responsiveness must be addressed in larger cohorts and by taking into account the genotype of the subjects in the control groups.

Possible mechanism for postreceptor GH resistance: Study of GH signaling in NS mouse model

As shown above, clinical data strongly suggested that defective growth in NS could be linked to postreceptor GH resistance. Considering that the mechanism of partial insensitivity to $\mathrm{GH}$ is unknown, it is worthwhile to explore the signaling pathways downstream of the $\mathrm{GH}$ receptor and possibly involved in $\mathrm{GH}$ resistance. Among all the genes causing NS, only the role of
PTPN11/Shp2 mutants has been adressed thus far. Shp2 is an ubiquitous protein tyrosine phosphatase which is preferentially activated by receptor tyrosine kinases, including cytokine receptors such as the $\mathrm{GH}$ receptor. In the following section, we will present the knowledge of Shp2 contribution to GH signaling as it is currently envisioned in healthy subjects, then in a NS mouse model.

The current view of signaling pathways involving PTPN11/ Shp2 downstream of GH receptor in healthy subjects When considering as a whole the molecular mechanisms resulting from $\mathrm{GH}$ binding to its membrane receptor, it begins with activation of the $\mathrm{GH}$ receptor-associated cytoplasmic tyrosine kinase, Janus kinase-2 (JAK2). GH-induced JAK2 stimulation leads to engagement of three major intracellular signaling pathways, namely the signal transducer and activator of transcription-5 (STAT5), the phosphoinositide 3-kinase (PI3K) and the Ras/MAPK pathways. These signaling modules are thought to mediate virtually all of GH biological activities [56].

Regarding the specific involvement of Shp2 in GH signaling, only a few studies have addressed this question, despite its interest from both fundamental and pathophysiological points of view. Two different research groups reported that Shp2 is rapidly recruited during cell stimulation with $\mathrm{GH}$, which suggested that this phosphatase is a significant signaling intermediate downstream of the $\mathrm{GH}$ receptor $[\mathbf{5 7}, \mathbf{5 8}]$. In addition, the adapter protein Gab-1 was found to be significantly phosphorylated in a preadipocyte murine cell line stimulated with GH [59] (our unpublished data). This observation strengthened the idea that Shp2 could participate in $\mathrm{GH}$ receptor signaling, since a major general function for phosphorylated Gab-1 consist in mediating Shp2 activation in response to various stimuli $[60,61]$.

Once activated, Shp2 most certainly plays a role in $\mathrm{GH}$ receptor signaling but its function downstream of this receptor is unclear. Studies in transfected cells over expressing either wild type Shp2, or Shp2 forms defective for one of its molecular functions, suggested that the phosphatase could act as a negative regulator of $\mathrm{GH}$ receptor signaling, possibly by dephosphorylating STAT5A $[62,63]$. Nevertheless, although these findings have been reported more than ten years ago, they remain to be validated in different cell types and in animal models. Moreover, research presented in the following paragraphs does not argue in favor of a major role of Shp2 in STAT5 regulation.

\section{Role of PTPN11/Shp2 mutant causing NS in Ras/MAPK upregulation and GH resistance in a NS mouse model}

The notion that short stature in NS could be linked with GH resistance was recently reinforced by a study taking advantage of a mouse model expressing a Shp2 mutant which corresponds to a mutation causing NS in human (PTPN11 1 D616/+ $)$ [5]. These mice exhibit a smaller size, which is associated with lower blood concentrations of IGF-1 and IGFBP-3 than in wild 


\section{Healthy subject}

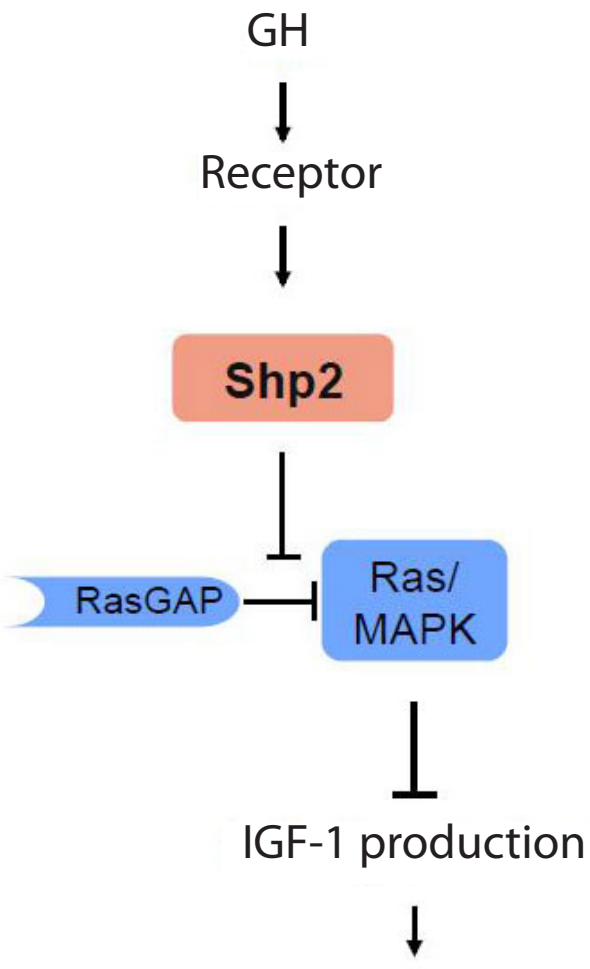

Normal growth

\section{Patient with NS}

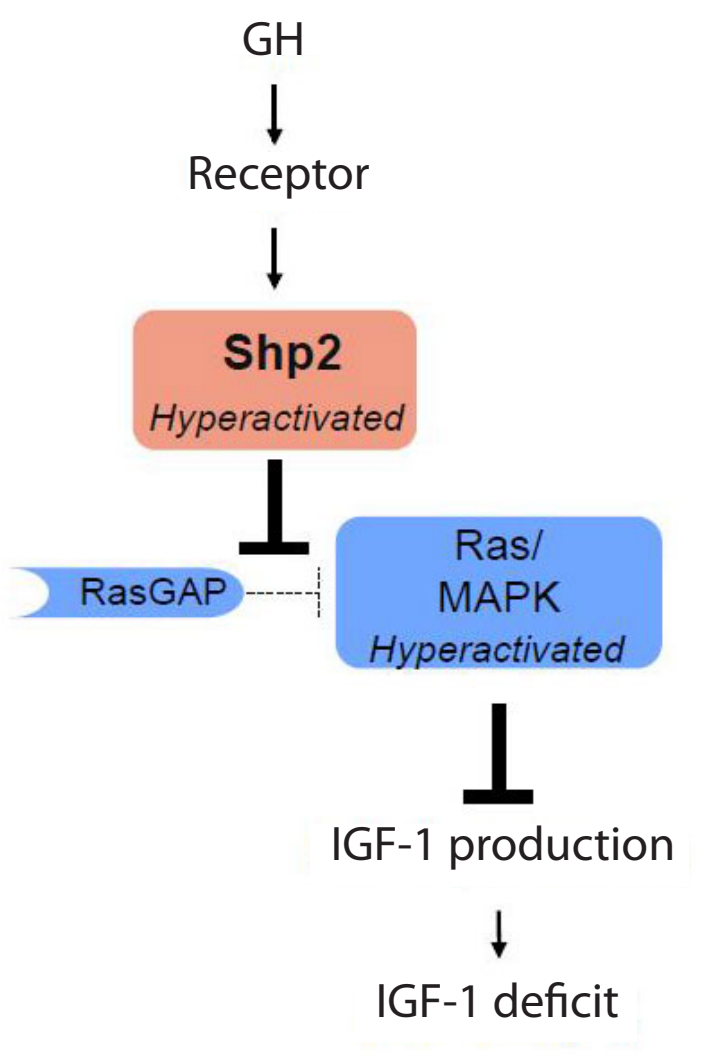

Shot stature

Figure 1. Somatotrope axis and role of Shp2 in the mechanism of GH resistance in NS. In healthy individuals (left), GH stimulates the production of IGF-1 which is directly involved in the control of long bones. Recent data show that Ras/MAPK plays a negative regulatory role on IGF-1 production, as well as Shp2 which can upregulate Ras/MAPK activation through dephosphorylation of binding sites for p120-RasGAP (a natural inhibitor of Ras). In patients with NS harboring PTPN11/Shp2 mutations (right), Shp2 is activated to a higher-than-normal level. This causes in turn an hyperactivation of Ras/MAPK, due to increased dephosphorylation by Shp2 of p120-RasGAP binding sites. Then, upregulation of Ras/MAPK leads to a reduction in IGF-1 production, which ultimately causes IGF-1 deficit and short stature [64].

type animals [64]. Therefore this mouse model appeared to present similar endocrine dysregulations as those observed in children with NS. This led us to explore the impact of this mutant on GH signaling, which was achieved in transfected cells. We thus observed that, in cells stimulated with $\mathrm{GH}$, the mutant produced higher-than-normal activation of Ras/MAPK, whereas STAT5 and PI3K pathways appeared to respond with normal intensity to $\mathrm{GH}$ stimulation. The molecular mechanism of this Ras/MAPK upregulation was found to involve increased dephosphorylation by a NS-causing Shp2 mutant of a binding site for p120-RasGAP (GTPase activating protein), a negative regulator of Ras. Therefore, enhanced dephosphorylation of this binding site by the mutant results in downregulation of
p120-RasGAP recruitment in GH-induced signaling complexes, which eventually produces an increased activation of Ras $[64,65]$ (see Figure 1 for schematic representation of this regulation).

Interestingly, this study also showed that treating NS mice with a Mek inhibitor restores IGF-1 level and increases their growth [64]. In agreement with this, earlier reports incidentally showed that Mek inhibitors can rescue growth defect in other NS mouse models (RAF1 ${ }^{1613 \mathrm{~V} /+}$ and SOS1 ${ }^{\mathrm{E} 46 \mathrm{~K} / \mathrm{E} 846 \mathrm{~K}}$ ) $[7,66]$. Altogether, these reports suggest that pharmacological regulation of Ras/MAPK could be an alternative approach to treat short stature in NS patients, even though a lot requires to be accomplished to assess the efficacy and safety of these 
Patrick Raynal Hormonal Studies 2014,

future treatments, in comparison with GH therapy.

Finally, the emerging concept that NS patients display GH resistance also suggests that an alternative treatment for short stature could be provided by recombinant human IGF-1 (rhIGF-1). This therapy is currently used to treat patients with severe GH insensitivity (e.g., patients with Laron syndrome, caused by absent or defective GH receptor) [67]. Therefore, even if the efficacy of rhIGF-1 to treat severe GH resistance is currently debated [68], this treatment could be helpful in NS patients, possibly in combination with GH therapy to improve its efficiency.

\section{Conclusions}

The future of GH therapy in NS remains difficult to predict, as prospective longer duration studies are still required to determine the effect of $\mathrm{GH}$ therapy on height and to establish the links between response to treatment and genotype. One can assume that the entry on the market of GH generics and of IGF-1 will offer more opportunities and perspectives for the clinicians. However, even though recent progress was made in understanding the cause of short stature in NS, further studies are required to decipher the mechanisms of growth retardation in NS, with the aim of improving the therapy outcome. Whereas it is relatively clear that these mechanisms should involve $\mathrm{GH}$ resistance due to dysfuntion in postreceptor signaling, the only defect identified thus far is an hyperactivation of Ras/MAPK in response to $\mathrm{GH}$, observed in NS mice. This may thus appear paradoxical with the fact that patients can be treated by increasing their $\mathrm{GH}$ level. Indeed it seems difficult to imagine that increasing GH concentration in NS patients leads to a downregulation of Ras/MAPK activation to a normal level, which may thus explain the modest outcomes of GH therapy in NS. Consequently additional work must be performed to address how GH therapy can compensate for Ras/MAPK hyperstimulation in NS.

\section{List of abbreviations}

ALS: acid-labile subunit

BRAF: gene encoding the isoform $B$ of rapidly

accelerated fibrosarcoma protein

GAP: GTPase-activating protein

$\mathrm{GH}$ : growth hormone

IGF-1: insulin-like growth factor-1

IGFBP-3: insulin-like growth factor-binding protein-3

JAK-2: Janus kinase-2

MAPK: mitogen-activated protein kinase

NS: Noonan syndrome

PI3K: phosphoinositide 3-kinase

PTPN11: protein tyrosine phosphatase non-receptor type 11

RAF1: gene encoding the isoform $C$ of rapidly

accelerated fibrosarcoma protein

rhIGF-1: recombinant human IGF-1

SDS: standard deviation score

SHOC2: Soc-2 suppressor of clear homolog (C. elegans)

SHP2: Src-homology type 2 domain-containing

protein tyrosine phosphatase-2

SOS1: son of sevenless-1

STAT: signal transducer and activator of transcription

\section{Competing interests}

The author declares that he has no competing interests.

\section{Acknowledgement and funding}

Research in the laboratory is supported by Institute National de la Santé et de la Recherche Médicale, ERANet E-Rare program (NSEuroNet), Agence nationale pour la Recherche, Association pour la Recherche sur le Cancer et Ligue Nationale Contre le Cancer.

\section{Publication history}

Editor: Cheng Wang, University of Nebraska Medical Center, USA. EIC: Masayoshi Yamaguchi, Emory University School of Medicine, USA.

Received: 25-Jul-2013 Revised: 13-Sep-2013

Accepted: 18-Nov-2013 Published: 17-Jan-2014

\section{References}

1. Aoki Y, Niihori T, Banjo T, Okamoto N, Mizuno S, Kurosawa K, Ogata T, Takada F, Yano M and Ando T et al. Gain-of-function mutations in RIT1 cause Noonan syndrome, a RAS/MAPK pathway syndrome. Am J Hum Genet. 2013; 93:173-80. | Article | PubMed

2. Tartaglia M, Gelb BD and Zenker M. Noonan syndrome and clinically related disorders. Best Pract Res Clin Endocrinol Metab. 2011; 25:161-79. | Article | PubMed Abstract | PubMed Full Text

3. Roberts AE, Allanson JE, Tartaglia M and Gelb BD. Noonan syndrome. Lancet. 2013; 381:333-42. | Article I PubMed

4. Chacko E, Graber E, Regelmann MO, Wallach E, Costin G and Rapaport R. Update on Turner and Noonan syndromes. Endocrinol Metab Clin North Am. 2012; 41:713-34. | Article | PubMed

5. Araki T, Mohi MG, Ismat FA, Bronson RT, Williams IR, Kutok JL, Yang W, Pao LI, Gilliland DG, Epstein JA and Neel BG. Mouse model of Noonan syndrome reveals cell type- and gene dosage-dependent effects of Ptpn11 mutation. Nat Med. 2004; 10:849-57. | Article | PubMed

6. Nakamura T, Colbert M, Krenz M, Molkentin JD, Hahn HS, Dorn GW, 2nd and Robbins J. Mediating ERK 1/2 signaling rescues congenital heart defects in a mouse model of Noonan syndrome. J Clin Invest. 2007; 117:2123-32. | Article | PubMed Abstract | PubMed Full Text

7. Chen PC, Wakimoto $H$, Conner D, Araki T, Yuan T, Roberts A, Seidman C, Bronson R, Neel B, Seidman JG and Kucherlapati R. Activation of multiple signaling pathways causes developmental defects in mice with a Noonan syndrome-associated Sos1 mutation. J Clin Invest. 2010; 120:4353-65. | Article | PubMed Abstract | PubMed Full Text

8. Ranke MB, Heidemann P, Knupfer C, Enders H, Schmaltz AA and Bierich JR. Noonan syndrome: growth and clinical manifestations in 144 cases. Eur J Pediatr. 1988; 148:220-7. | Article | PubMed

9. Noonan JA, Raaijmakers R and Hall BD. Adult height in Noonan syndrome. Am J Med Genet A. 2003; 123A:68-71. | $\underline{\text { Article I PubMed }}$

10. Otten BJ and Noordam C. Growth in Noonan syndrome. Horm Res. 2009; 72 Suppl 2:31-5. | Article | PubMed

11. Witt DR, Keena BA, Hall JG and Allanson JE. Growth curves for height in Noonan syndrome. Clin Genet. 1986; 30:150-3. I Article I PubMed

12. Shaw AC, Kalidas K, Crosby AH, Jeffery $S$ and Patton MA. The natural history of Noonan syndrome: a long-term follow-up study. Arch Dis Child. 2007; 92:128-32. | Article | PubMed Abstract | PubMed Full Text

13. Binder G, Grathwol S, von Loeper K, Blumenstock G, Kaulitz R, Freiberg C, Webel M, Lissewski C, Zenker $\mathrm{M}$ and Paul T. Health and quality of life in adults with Noonan syndrome. J Pediatr. 2012; 161:501-505 e1. I Article | PubMed

14. Malaquias AC, Brasil AS, Pereira AC, Arnhold IJ, Mendonca BB, Bertola DR and Jorge AA. Growth standards of patients with Noonan and Noonanlike syndromes with mutations in the RAS/MAPK pathway. Am J Med Genet A. 2012; 158A:2700-6. | Article I PubMed

15. Wang SR, Carmichael H, Andrew SF, Miller TC, Moon JE, Derr MA, Hwa 
Patrick Raynal Hormonal Studies 2014,

V, Hirschhorn JN and Dauber A. Large-scale pooled next-generation sequencing of 1077 genes to identify genetic causes of short stature. $J$ Clin Endocrinol Metab. 2013; 98:E1428-37. | Article | PubMed

16. Roberts AE, Araki T, Swanson KD, Montgomery KT, Schiripo TA, Joshi VA, Li L, Yassin Y, Tamburino AM, Neel BG and Kucherlapati RS. Germline gain-of-function mutations in SOS1 cause Noonan syndrome. Nat Genet. 2007; 39:70-4. | Article | PubMed

17. Tartaglia M, Pennacchio LA, Zhao C, Yadav KK, Fodale V, Sarkozy A, Pandit B, Oishi K, Martinelli S and Schackwitz W et al. Gain-of-function SOS1 mutations cause a distinctive form of Noonan syndrome. Nat Genet. 2007; 39:75-9. | Article | PubMed

18. Zenker M, Horn D, Wieczorek D, Allanson J, Pauli S, van der Burgt I, Doerr HG, Gaspar H, Hofbeck M and Gillessen-Kaesbach G et al. SOS1 is the second most common Noonan gene but plays no major role in cardiofacio-cutaneous syndrome. J Med Genet. 2007; 44:651-6. | Article | PubMed Abstract | PubMed Full Text

19. Ko JM, Kim JM, Kim GH and Yoo HW. PTPN11, SOS1, KRAS, and RAF1 gene analysis, and genotype-phenotype correlation in Korean patients with Noonan syndrome. J Hum Genet. 2008; 53:999-1006. | Article | PubMed

20. Kobayashi T, Aoki Y, Niihori T, Cave H, Verloes A, Okamoto N, Kawame H, Fujiwara I, Takada F and Ohata $\mathrm{T}$ et al. Molecular and clinical analysis of RAF1 in Noonan syndrome and related disorders: dephosphorylation of serine $\mathbf{2 5 9}$ as the essential mechanism for mutant activation. Hum Mutat. 2010; 31:284-94. | Article | PubMed

21. Cordeddu V, Di Schiavi E, Pennacchio LA, Ma'ayan A, Sarkozy A, Fodale V, Cecchetti S, Cardinale A, Martin J and Schackwitz W et al. Mutation of SHOC2 promotes aberrant protein $\mathrm{N}$-myristoylation and causes Noonan-like syndrome with loose anagen hair. Nat Genet. 2009; 41:1022-6. | Article | PubMed Abstract | PubMed Full Text

22. Kirk JM, Betts PR, Butler GE, Donaldson MD, Dunger DB, Johnston DI, Kelnar CJ, Price DA, Wilton P and Group t U. Short stature in Noonan syndrome: response to growth hormone therapy. Arch Dis Child. 2001; 84:440-3. | Article | PubMed Abstract | PubMed Full Text

23. MacFarlane CE, Brown DC, Johnston LB, Patton MA, Dunger DB, Savage $\mathrm{MO}$, McKenna WJ and Kelnar CJ. Growth hormone therapy and growth in children with Noonan's syndrome: results of 3 years' follow-up. J Clin Endocrinol Metab. 2001; 86:1953-6. | Article | PubMed

24. Ogawa M, Moriya N, Ikeda H, Tanae A, Tanaka T, Ohyama K, Mori O, Yazawa T, Fujita K, Seino Y, Kubo T, Tanaka H, Nishi Y and Yoshimoto M. Clinical evaluation of recombinant human growth hormone in Noonan syndrome. Endocr J. 2004; 51:61-8. | Article | PubMed

25. Binder G, Neuer K, Ranke MB and Wittekindt NE. PTPN11 mutations are associated with mild growth hormone resistance in individuals with Noonan syndrome. J Clin Endocrinol Metab. 2005; 90:5377-81. | Article I PubMed

26. Osio D, Dahlgren J, Wikland KA and Westphal O. Improved final height with long-term growth hormone treatment in Noonan syndrome. Acto Paediatr. 2005; 94:1232-7. | Article | PubMed

27. Limal JM, Parfait B, Cabrol S, Bonnet D, Leheup B, Lyonnet S, Vidaud M and Le Bouc Y. Noonan syndrome: relationships between genotype, growth, and growth factors. J Clin Endocrinol Metab. 2006; 91:300-6. | Article I PubMed

28. Noordam C, Peer PG, Francois I, De Schepper J, van den Burgt I and Otten BJ. Long-term GH treatment improves adult height in children with Noonan syndrome with and without mutations in protein tyrosine phosphatase, non-receptor-type 11. Eur J Endocrinol. 2008; 159:203-8. I Article | PubMed

29. Raaijmakers R, Noordam C, Karagiannis G, Gregory JW, Hertel NT, Sipila I and Otten BJ. Response to growth hormone treatment and final height in Noonan syndrome in a large cohort of patients in the KIGS database. $J$ Pediatr Endocrinol Metab. 2008; 21:267-73. | Article | PubMed

30. Romano AA, Dana K, Bakker B, Davis DA, Hunold JJ, Jacobs J and Lippe $B$. Growth response, near-adult height, and patterns of growth and puberty in patients with noonan syndrome treated with growth hormone. J Clin Endocrinol Metab. 2009; 94:2338-44. | Article | PubMed

31. Lee PA, Ross J, Germak JA and Gut R. Effect of 4 years of growth hormone therapy in children with Noonan syndrome in the American Norditropin Studies: Web-Enabled Research (ANSWER) Program(R) registry. Int J Pediatr Endocrinol. 2012; 2012:15. | Article | PubMed Abstract | PubMed Full Text

32. Bechtold S, Dalla Pozza R, Schmidt H, Bonfig W and Schwarz HP. Pubertal height gain in Ullrich-Turner syndrome. J Pediatr Endocrinol Metab. 2006; 19:987-93. | Article | PubMed

33. Westphal O. Growth hormone therapy in Noonan syndrome: growth response and characteristics. Horm Res. 2009; 72 Suppl 2:41-5. | Article I PubMed

34. Verhoeven W, Wingbermuhle E, Egger J, Van der Burgt I and Tuinier S. Noonan syndrome: psychological and psychiatric aspects. Am J Med Genet A. 2008; 146A:191-6. | Article | PubMed

35. Smpokou P, Tworog-Dube E, Kucherlapati RS and Roberts AE. Medical complications, clinical findings, and educational outcomes in adults with Noonan syndrome. Am J Med Genet A. 2012; 158A:3106-11. | Article | PubMed

36. Cuttler $L$ and Rosenfield RL. Assessing the value of treatments to increase height. N Engl J Med. 2011; 364:1274-6. | Article | PubMed

37. Silvers JB, Marinova D, Mercer MB, Connors A and Cuttler L. A national study of physician recommendations to initiate and discontinue growth hormone for short stature. Pediatrics. 2010; 126:468-76. | Article | PubMed

38. Noordam C, Van der Burgt I, Sengers RC, Delemarre-van de Waal HA and Otten BJ. Growth hormone treatment in children with Noonan's syndrome: four year results of a partly controlled trial. Acta Paediatr. 2001; 90:889-94. | Article | PubMed

39. Isgaard J. Cardiovascular disease and risk factors: the role of growth hormone. Horm Res. 2004; 62 Suppl 4:31-8. | Article | PubMed

40. Cotterill AM, McKenna WJ, Brady AF, Sharland M, Elsawi M, Yamada M, Camacho-Hubner C, Kelnar CJ, Dunger DB, Patton MA and Savage MO. The short-term effects of growth hormone therapy on height velocity and cardiac ventricular wall thickness in children with Noonan's syndrome. J Clin Endocrinol Metab. 1996; 81:2291-7. | Article | PubMed

41. Noordam C, Draaisma JM, van den Nieuwenhof J, van der Burgt I, Otten BJ and Daniels O. Effects of growth hormone treatment on left ventricular dimensions in children with Noonan's syndrome. Horm Res. 2001; 56:110-3. | Article | PubMed

42. Brown DC, Macfarlane CE, McKenna WJ, Patton MA, Dunger DB, Savage $\mathrm{MO}$ and Kelnar $\mathrm{CJ}$. Growth hormone therapy in Noonan's syndrome: non-cardiomyopathic congenital heart disease does not adversely affect growth improvement. J Pediatr Endocrinol Metab. 2002; 15:851-2. | Article | PubMed

43. Noordam C. Growth hormone and the heart in Noonan syndrome. Horm Res. 2009; 72 Suppl 2:49-51. | Article | PubMed

44. Romano AA, Allanson JE, Dahlgren J, Gelb BD, Hall B, Pierpont ME, Roberts $A E$, Robinson W, Takemoto CM and Noonan JA. Noonan syndrome: clinical features, diagnosis, and management guidelines. Pediatrics. 2010; 126:746-59. | Article | PubMed

45. Hasle H. Malignant diseases in Noonan syndrome and related disorders. Horm Res. 2009; 72 Suppl 2:8-14. | Article | PubMed

46. Moos D, Droitcourt C, Rancherevince D, Marec Berard P and Skowron F. Atypical granular cell tumor occurring in an individual with Noonan syndrome treated with growth hormone. Pediatr Dermatol. 2012; 29:665-6. | Article | PubMed

47. He Z, Zhang SS, Meng Q, Li S, Zhu HH, Raquil MA, Alderson N, Zhang H, Wu J, Rui L, Cai D and Feng GS. Shp2 controls female body weight and energy balance by integrating leptin and estrogen signals. Mol Cell Biol. 2012; 32:1867-78. | Article | PubMed Abstract | PubMed Full Text

48. Noordam C, van der Burgt I, Sweep CG, Delemarre-van de Waal HA, Sengers RC and Otten BJ. Growth hormone (GH) secretion in children with Noonan syndrome: frequently abnormal without consequences for growth or response to GH treatment. Clin Endocrinol (Oxf). 2001; 54:53-9. | Article | PubMed

49. Lee CK, Chang BS, Hong YM, Yang SW, Lee CS and Seo JB. Spinal deformities in Noonan syndrome: a clinical review of sixty cases. $J$ Bone 
Patrick Raynal Hormonal Studies 2014,

Joint Surg Am. 2001; 83-A:1495-502. | Article | PubMed

50. Stevenson DA and Yang FC. The musculoskeletal phenotype of the RASopathies. Am J Med Genet C Semin Med Genet. 2011; 157C:90-103. | Article | PubMed

51. Choudhry KS, Grover M, Tran AA, O'Brian Smith E, Ellis KJ and Lee BH. Decreased bone mineralization in children with Noonan syndrome: another consequence of dysregulated RAS MAPKinase pathway? Mol Genet Metab. 2012; 106:237-40. | Article | PubMed Abstract | PubMed Full Text

52. Bauler TJ, Kamiya N, Lapinski PE, Langewisch E, Mishina Y, Wilkinson $J E$, Feng GS and King PD. Development of severe skeletal defects in induced SHP-2-deficient adult mice: a model of skeletal malformation in humans with SHP-2 mutations. Dis Model Mech. 2011; 4:228-39. | Article | PubMed Abstract | PubMed Full Text

53. Ferreira LV, Souza SA, Arnhold IJ, Mendonca BB and Jorge AA. PTPN11 (protein tyrosine phosphatase, nonreceptor type 11) mutations and response to growth hormone therapy in children with Noonan syndrome. J Clin Endocrinol Metab. 2005; 90:5156-60. | Article | PubMed

54. Choi JH, Lee BH, Jung CW, Kim YM, Jin HY, Kim JM, Kim GH, Hwang JS, Yang SW, Lee J and Yoo HW. Response to growth hormone therapy in children with Noonan syndrome: correlation with or without PTPN11 gene mutation. Horm Res Paediatr. 2012; 77:388-93. | Article | PubMed

55. Bertelloni S, Baroncelli GI, Dati E, Ghione S, Baldinotti F, Toschi B and Simi P. IGF-I generation test in prepubertal children with Noonan syndrome due to mutations in the PTPN11 gene. Hormones (Athens). 2013; 12:8692. | Article | PubMed

56. Lanning NJ and Carter-Su C. Recent advances in growth hormone signaling. Rev Endocr Metab Disord. 2006; 7:225-35. | Article | PubMed

57. Stofega MR, Wang H, Ullrich A and Carter-Su C. Growth hormone regulation of SIRP and SHP-2 tyrosyl phosphorylation and association. J Biol Chem. 1998; 273:7112-7. | Article | PubMed

58. Kim SO, Jiang J, Yi W, Feng GS and Frank SJ. Involvement of the Src homology 2-containing tyrosine phosphatase SHP-2 in growth hormone signaling. J Biol Chem. 1998; 273:2344-54. | Article | PubMed

59. Kim SO, Loesch K, Wang X, Jiang J, Mei L, Cunnick JM, Wu J and Frank SJ. A role for Grb2-associated binder-1 in growth hormone signaling. Endocrinology. 2002; 143:4856-67. | Article | PubMed

60. Schaeper U, Vogel R, Chmielowiec J, Huelsken J, Rosario M and Birchmeier W. Distinct requirements for Gab1 in Met and EGF receptor signaling in vivo. Proc Natl Acad Sci U S A. 2007; 104:15376-81. | Article | PubMed Abstract | PubMed Full Text

61. Bard-Chapeau EA, Yuan J, Droin N, Long S, Zhang EE, Nguyen TV and Feng GS. Concerted functions of Gab1 and Shp2 in liver regeneration and hepatoprotection. Mol Cell Biol. 2006; 26:4664-74. | Article | PubMed Abstract | PubMed Full Text

62. Stofega MR, Argetsinger LS, Wang H, Ullrich A and Carter-Su C. Negative regulation of growth hormone receptor/JAK2 signaling by signal regulatory protein alpha. J Biol Chem. 2000; 275:28222-9. | Article | PubMed

63. Chen Y, Wen R, Yang S, Schuman J, Zhang EE, Yi T, Feng GS and Wang D. Identification of Shp-2 as a Stat5A phosphatase. J Biol Chem. 2003; 278:16520-7. | Article | PubMed

64. De Rocca Serra-Nedelec A, Edouard T, Treguer K, Tajan M, Araki T, Dance M, Mus M, Montagner A, Tauber M, Salles JP, Valet P, Neel BG, Raynal $P$ and Yart A. Noonan syndrome-causing SHP2 mutants inhibit insulin-like growth factor 1 release via growth hormone-induced ERK hyperactivation, which contributes to short stature. Proc Natl Acad Sci U S A. 2012; 109:4257-62. | Article | PubMed Abstract | PubMed Full Text

65. Montagner A, Yart A, Dance M, Perret B, Salles JP and Raynal P. A novel role for Gab1 and SHP2 in epidermal growth factor-induced Ras activation. J Biol Chem. 2005; 280:5350-60. | Article | PubMed

66. Wu X, Simpson J, Hong JH, Kim KH, Thavarajah NK, Backx PH, Neel $B G$ and Araki T. MEK-ERK pathway modulation ameliorates disease phenotypes in a mouse model of Noonan syndrome associated with the Raf1(L613V) mutation. J Clin Invest. 2011; 121:1009-25. | Article |
PubMed Abstract | PubMed Full Text

67. Chernausek SD. Growth hormone-resistant syndromes: long-term follow-up. Endocr Dev. 2009; 14:135-42. | Article | PubMed

68. Bang P, Ahmed SF, Argente J, Backeljauw P, Bettendorf M, Bona G, Coutant $R$, Rosenfeld RG, Walenkamp MJ and Savage MO. Identification and management of poor response to growth-promoting therapy in children with short stature. Clin Endocrinol (Oxf). 2012; 77:169-81. | Article | PubMed

\section{Citation:}

Raynal P. Growth hormone and noonan syndrome: update in dysfunctional signaling aspects and in therapy for short stature. Horm Stud. 2014; 2:1. http://dx.doi.org/10.7243/2052-8000-2-1 